\title{
EFFECTS OF LIGHT ON THE PROPAGATION AND GROWTH OF BULBS OF HIPPEASTRUM HYBRIDUM cv. APPLE BLOSSOM (Amaryllidaceae)
}

\author{
G.C. STANCATO'; P. MAZZAFERA ${ }^{2,3}$ \\ 1- Instituto de Botânica, C.P. 4005, CEP: 01061-970, São Paulo, SP \\ 2 - Departamento de Fisiologia Vegetal, Instituto de Biologia, UNICAMP, C.P. 6109, CEP: 13081-970, Campinas, SP
}

\begin{abstract}
Commerclally bulbs of Hippeastrum hybridum are propagated by twin scales, which are cultured in wet vermiculite in the darkness until bulbil appearance. We showed that twin scales kept under sun light produced bulbils, that once transferred to the field, did not undergo severe light stress. They had higher bulb dry weight and due to the presence of green leaves they grew faster when transplanted to the fleld than bulbils produced from scales kept in the darkness. An intermediary treatment (a period of darkness followed by transference to light) confirmed the advantages of producing bulbils under sun light conditions. It appears that in the field, growth of bulbs from dark grown bulbils was retarded due to the strong competition among leaves and roots for nutrients and assimilates.
\end{abstract}

Key Words: Amaryllidaceae, bulbils production, Hippeastrum hybridum, vegetative propagation

\section{EFEITOS DA LUZ NA PROPAGAÇÃO E CRESCIMENTO DE BULBOS DE Hippeastrum hibridum cv. APPLE BLOSSOM (Amaryllidaceae)}

RESUMO: Comercialmente, bulbos de Hippeastrum hybridum sāo propagados por escamas duplas, as quais são mantidas em vermiculita umedecida e no escuro até o aparecimento do bulbilho. No presente trabalho demonstrou-se que escamas duplas mantidas sob luz solar plena produziram bulbilhos que uma vez transferidos para condiçōes de campo não sofreram o estresse imposto pela luz. Tais bulbilhos possuíam maior peso seco de bulbo e, devido a presença de folhas verdes, cresceram mais rápido do que bulbilhos produzidos no escuro. Um tratamento intermediário, em que as escamas foram mantidas na escuridão por um periodo e depois transferidas para a luz, confirmou as vantagens em se produxir bulbilhos na luz. Muito provavelmente, bulbilhos produzidos no escuro tiveram seu desenvolvimento atrasado devido a forte competição entre folhas e raizes por nutrientes e fotoassimilados.

Descritores: Amaryllidaceae, Hippeastrum hybridum, produção de bulbilhos, propagação vegetativa

\section{INTRODUCTION}

In recent years the interest for flower bulbs as ornamental crops has increased significantly and, as a consequence, the cultivation area has also become larger in many countries. Most of the flower bulbs are cultivated in their native habitat condition, in general found in tropical and sub-tropical countries, or under artificial conditions in greenhouses. Therefore, information on their adaptation to different conditions of temperature, humidity and light are important.

Hippeastrum is a genus of flower bulbs comprising among 60 to 70 species (REES, 1985). More than 300 varieties are known, presenting a vast range of colors and color combinations. Most of the Hippeastrum produced in the world is traded in countries of North America and Europe (STANCATO, 1993).

(Schoenmaker and de Wit, personal communication).

3 - Bolsista do CNPq

Sci. agric., Piracicaba, 52 (2):331-334, mai./ago. 1995
Hippeastrum is propagated by twin scale (HUANG et al., 1990). However, as well as for Narcissus (HANKS \& REES, 1979), most of the investigations on propagating conditions were more concerned about temperature influence. Though for both plants twin scales incubation has been carried out in the light, up to date no comparison was made with dark incubation. However, in commercial scale, Hippeastrum has been propagated in wet vermiculite in the darkness, at temperatures above $30^{\circ} \mathrm{C}$. After three to four weeks bulbils primordia can be observed in the junction of the scales and basal plate. A few months later they are transferred to the field and after two or three years the bulbs are ready to be commercialized.

Concerned about that bulbils propagated in the darkness undergo severe light stress when transferred to field conditions, in this study we compared Hippeastrum bulbil propagation with twin scales kept under light and darkness. 
MATERIALS AND METHODS

Plant material and bulbil production. Bulbs of Hippeastrum hybridum cv. Apple Blossom were used in the experiments. Twin scales, obtained by longitudinal cutting of the bulb (HUANG et al.,
1990), were inserted in vermiculite swollen in tap water and the boxes were put in a glass chamber with relative humidity at $60 \pm 10 \%$ and temperature oscilating between $20^{\circ} \mathrm{C}$ and $40^{\circ} \mathrm{C}$. This humid chamber was in a greenhouse which received direct sun light. The scales were kept in this glass chamber

TABLE 1. Number of leaves, leaf area and dry weight of leaves, bulbs and roots of bulbils produced under light, darkness and dark/light conditions and transferred to the field.

\begin{tabular}{|c|c|c|c|c|}
\hline & $\begin{array}{c}\text { Day } \\
\text { sampling }\end{array}$ & Light & $\begin{array}{l}\text { Treatments } \\
\text { Dark }\end{array}$ & Dark/Light \\
\hline $\begin{array}{l}\text { Bulb dry weight } \\
\text { (mg) }\end{array}$ & $\begin{array}{r}0 \\
30 \\
60 \\
90 \\
150\end{array}$ & $\begin{array}{r}182 a \\
247 a \\
399 a \\
975 a \\
3704 a\end{array}$ & $\begin{array}{r}133 b \\
91 b \\
152 b \\
428 b \\
1656 b\end{array}$ & $\begin{array}{c}162 a \\
177 a \\
244 b \\
917 a \\
3445 a\end{array}$ \\
\hline $\begin{array}{l}\text { Leaves dry weight } \\
\text { (mg) }\end{array}$ & $\begin{array}{r}0 \\
30 \\
60 \\
90 \\
150\end{array}$ & $\begin{array}{r}106 a \\
195 a \\
512 a \\
962 a \\
3227 a\end{array}$ & $\begin{array}{r}28 \mathrm{c} \\
61 \mathrm{c} \\
176 \mathrm{c} \\
512 \mathrm{c} \\
1693 \mathrm{~b}\end{array}$ & $\begin{array}{r}91 b \\
121 b \\
359 b \\
1256 b \\
3136 a\end{array}$ \\
\hline $\begin{array}{l}\text { Root dry weight } \\
\text { (mg) }\end{array}$ & 0 & $70 a$ & $16 \mathrm{c}$ & $58 \mathrm{~b}$ \\
\hline $\begin{array}{c}\text { Total dry weight } \\
\text { (mg) }\end{array}$ & $\begin{array}{r}0 \\
30 \\
60 \\
90 \\
150\end{array}$ & $\begin{array}{c}358 a \\
442 a \\
911 a \\
1936 a \\
6931 a\end{array}$ & $\begin{array}{c}161 \mathrm{c} \\
152 \mathrm{c} \\
328 \mathrm{c} \\
940 \mathrm{~b} \\
3347 \mathrm{~b}\end{array}$ & $\begin{array}{r}253 b \\
297 b \\
603 b \\
2173 a \\
6581 a\end{array}$ \\
\hline $\begin{array}{l}\text { Leaf area } \\
(\mathrm{cm} 2)\end{array}$ & $\begin{array}{r}0 \\
30 \\
60 \\
90 \\
150\end{array}$ & $\begin{array}{r}31 a \\
40 a \\
82 a \\
146 a \\
394 a\end{array}$ & $\begin{array}{r}15 c \\
12 c \\
29 c \\
89 b \\
238 b\end{array}$ & $\begin{array}{r}22 b \\
23 b \\
57 b \\
168 a \\
361 a\end{array}$ \\
\hline Number of leaves & $\begin{array}{r}0 \\
30 \\
60 \\
150\end{array}$ & $\begin{array}{l}2.0 \mathrm{a} \\
2.8 \mathrm{a} \\
4.0 \mathrm{a} \\
5.2 \mathrm{ab}\end{array}$ & $\begin{array}{l}1.6 \mathrm{a} \\
2.0 \mathrm{~b} \\
2.0 \mathrm{c} \\
4.4 \mathrm{~b}\end{array}$ & $\begin{array}{l}2.0 \mathrm{a} \\
2.4 \mathrm{ab} \\
4.6 \mathrm{a} \\
5.6 \mathrm{a}\end{array}$ \\
\hline
\end{tabular}

1 Letters indicate statistical differences (Tukey $5 \%$ ) among the treatments in the same day of sampling

2 The results are means of five replicates

${ }^{3}$ Dry weight of roots at day 0 are included 
for 126 days (1 April to 4 August 1992), and they were subjected to three treatments: treatment 1 - no protection against sun light; treatment 2 - the box were wrapped in a double sided bag, with aluminum foil internally and glossy white paper externally; treatment 3 - the scales were kept for 62 days in darkness conditions, as described for treatment 2 , and then transferred to light, as in treatment 1 . Then the bulbils were transferred to soil in field conditions. The experiments were carried out in Campinas, Brasil (latitude (S) $22^{\circ} 53^{\prime}$, longitude (W) $\left.47^{\circ} 05^{\prime}\right)$.

Sampling and analysis. From 4 August 1992 to 1 January 1993 bulbils were collected at 0,30 , 60,90 and 150 days after transplanting to the field. Five bulbils were collected from each treatment and they were separated in bulb and leaves. For the first sampling (day 0 ), roots were also collected. The leaf areas were determined with a $\mathrm{Li}-\mathrm{Cor} \mathrm{Li}-3000$ leaf area integrator (Lambda Instruments). Leaf disks $(0,5 \mathrm{~cm}$ in diameter) from the central portion were taken for chlorophyll analysis. Dry weight of leaves and bulbs were obtained after drying at $80^{\circ} \mathrm{C}$ until constant dry weight. Since the leaf area and the size of leaf disks were known, it was possible to recompose the total dry weight of the leaves. Chlorophyll was determined according to ARNON (1949).

\section{RESULTS AND DISCUSSION}

Bulbils produced under sun light accumulated more organic matter than those from the other treatments (TABLE 1). At day 0 total dry weight was high for this treatment, intermediary for dark/light and low for bulbils from darkness. However, considering bulbs, leaves and roots separately, bulbils of the light and dark/light treatments had similar bulb dry weight, but leaves and roots differed significantly. Although similar leaf number in these treatments, dark/light bulbils had at day 0 a lower leaf area. Therefore, it seems that

TABLE 2. Chlorophyll content (greening) in leaves of bulbils of the light and dark treatments after transference to the field.

\begin{tabular}{llc}
\hline \hline Days & $\begin{array}{c}\text { Chlomphyll content }(\mu \mathrm{g} / \mathrm{g} \text { f.w.) } \\
\text { Light }{ }^{1,2}\end{array}$ & Dark \\
\hline 0 & $12.56 \mathrm{a}$ & $0.31 \mathrm{~b}$ \\
2 & $12.14 \mathrm{a}$ & $0.32 \mathrm{~b}$ \\
5 & $12.99 \mathrm{a}$ & $1.25 \mathrm{~b}$ \\
9 & $12.53 \mathrm{a}$ & $3.16 \mathrm{~b}$ \\
15 & $12.05 \mathrm{a}$ & $7.33 \mathrm{~b}$ \\
21 & $12.74 \mathrm{a}$ & $12.99 \mathrm{a}$ \\
\hline \hline
\end{tabular}

${ }^{1}$ Letters indicate statistical differences (Tukey $5 \%$ )

between the treatments in the same day of sampling

${ }^{2}$ The results are means of five replicates

TÀBLE 3. Ratios for bulb and leaves dry weight.

\begin{tabular}{lcccc}
\hline \hline & Ratio & Light & $\begin{array}{c}\text { Treatments } \\
\text { Dark }\end{array}$ & Dark/Light \\
\hline Bulb dry weight & $30 / 0$ & 1.35 & 0.68 & 1.09 \\
& $60 / 0$ & 2.20 & 1.13 & 1.50 \\
& $90 / 0$ & 5.38 & 3.20 & 5.68 \\
& $150 / 0$ & 20.46 & 12.44 & 21.39 \\
\hline Leaves dry weight & $30 / 0$ & 1.85 & 2.14 & 1.34 \\
& $60 / 0$ & 4.87 & 6.25 & 4.00 \\
& $90 / 0$ & 9.15 & 18.28 & 13.95 \\
& $150 / 0$ & 30.73 & 60.43 & 34.80 \\
\hline \hline
\end{tabular}


the bulbs are strong sinks even in early developmental stages of the bulbils.

After 30 days of transplanting, plants from the light and dark/light treatments had accumulated dry matter, while those from darkness showed a decrease in dry matter content (TABLE 1). At the transference from the darkness to light conditions, bulbils from dark/light treatment started to grew faster, presenting at the end of the experimental period similar dry matter content to plants of light treatment.

Due to leaves of dark grown bulbils were etiolated at the time of transplantation, part of tissue was damaged when exposed to sun light, causing death of tissue locally. Although chlorophyll content reached normal levels after 21 days, significant leaf grow was observed only between 30 and 60 days after transplanting. Recovery of dry weight of the bulbs of these plants was also observed between 30 and 60 days. At the end of the experiment the bulbs were $50 \%$ lighter than those of the other treatments.

In order to observe how dry matter accumulation proceeded in bulbs and leaves, the values of days $30,60,90$ and 150 were divided by that of the day 0 (TABLE 3). Bulbs of dark/light showed lower ratios than the light treatment, however, becoming similar at the end of the experiment. Bulbs of the dark treatment always accumulated lower amounts of dry matter. Interestingly, the opposite was observed for leaves dry weight. Following transplantation to the field, leaves of dark grown bulbils had higher ratios, suggesting that leaves, and probably roots, were competing with bulbs for photoassimilates and, therefore, depriving these latter of photoassimilates resulting in reduced growth.

FRONTANIER (1973) observed that the juvenile period in flower bulbs was closely related to a minimum weight of the bulbil. Therefore, reduction of the juvenile period due to a faster increase in weight would be of interest for bulbs produced in commercial scale. Also, there seems to be a close relation between bulb weight and flowering process in bulbous plants (REES, 1966; REES, 1972).

Bulbs of Hippeastrum are commercialized after two or three years in the field, when they attain a specific size and weight. Here we show that bulbils produced under natural sun light accumulated more dry matter than dark propagated bulbils and are better adapted to field conditions. Gain in weight is faster in this material because they are not subjected to light stress. Once the leaves are green, they are immediately able to photosynthesize at the new

Sci. agric., Piracicaba, 52(2):331-334, mai./ago. 1995 conditions, avoiding any temporary competition with the bulb for photoassimilates. As a consequence of a faster dry weight gain, there is a gain in cultivation time, since flowering is dependent of the bulb dry weight.

\section{CONCLUSIONS}

These results showed that propagation of Hippeastrum hybridum by twin scales under sunlight is advantageous compared to the traditional propagation in darkness. Light grown bulbils had the juvenile phase shortened since they did not undergo severe stress once transferred to field conditions.

\section{ACKNOWLEDGEMENTS}

We grateful acknowledge Schoenmaker \& Sons, Holambra, Brasil, for the Hippeastrum material and helpful informations during this work.

\section{REFERENCES}

ARNON, D.J. Copper enzymes in isolated chloroplasts polyphenoloxidase in Beta vulgaris. Plant Physiology, Bethesda, v.24, p.1-15, 1949.

FRONTANIER, E.J. Reviewing the length of the generation period and its shortening, particularly in tulips. Scientia Horticulturae, Amsterdam, v.1, p.107-116, 1973.

HANKS, G.R.; REES, A.R. Twin-scale propagation of Narcissus: A review. Scientia Horticulturae, Amsterdam, v.10, p.1-14, 1979.

HUANG, C.W., OKUBO, H.; UEMOTO, S. Importance of two scales in propagating Hippeastrum hybridum by twin scaling Scientia Horticulturae, Amsterdam, v.42, p.141$149,1990$.

REES, A.R. The physiology of omamental bulbous plants. Botanical Review, New York, v.32, p.1-23, 1966.

REES, A.R. The Growth of Bulbs - Applied Aspects of the Physiology of Ornamental Bulbous Crop Plants. London: Academic Press, 1972. 254p.

REES, A.R. Hippeastrum. In: HALEVY, A.H. (Ed). Handbook of Flowering. Boca Raton: CRC Press, 1985, v.1, p.294-296.

STANCATO, G.C. Fisiologia do crescimento em Hippeastrum hybridum cv. Apple Blossom: Relaçares fonte:dreno. Campinas, 1993. 52p. Tese (Mestrado) - Instituto de Biologia, Universidade Estadual de Campinas.

Recebido para publicação em 15.02.95

Aceito para publicação em 20.07 .95 